\title{
Herbicide Conversion of a Sand Shinnery Oak (Quercus havardii) Community: Effects on Biomass
}

\author{
W.E. SEARS, C.M. BRITTON, D.B. WESTER, AND R.D. PETTIT
}

\section{Abstract}

Seasonal biomass dynamics were documented in an undisturbed sand shinnery oak (Quercus havardii) community and adjacent areas treated with tebuthiuron 3 years and 6 years prior to sampling. Biomass was measured for above-ground and below-ground compartments during growth initiation, peak standing crop, and winter dormancy in 1981. Total biomass showed little change on plots treated 3 years prior to sampling compared to the untreated oak plot. However, there was a decrease in total biomass on the 6-year plot compared to the other 2 treatments. Above-ground biomass decreased on both treated sites compared to the untreated plot reflecting oak death and decomposition.. Above-ground herbaceous material increased appoximately 6-fold on both treated sites compared to the untreated plot. Oak root biomass decreased $12 \%$ at 3 years and $37 \%$ at 6 years following treatment. Herbaceous root biomass increased 3-fold on the 3-year-old treatment compared to the untreated oak community and was twice as much on the 6-year-old treatment compared to the untreated site. Distribution of herbaceous roots by soil depth was altered by treatment with a higher percentage of roots on the surface $30 \mathrm{~cm}$ on the treated sites compared to the untreated sites.

Sand shinnery oak (Quercus havardii) is a low-growing, rhizomatous shrub found primarily on deep sandy soils in northwestern Texas, eastern New Mexico, and western Oklahoma. As a component of the High Plains postclimax bluestem community (Allred 1956), it occurs as extensive "shinnery," forming dense thickets 0.5 to $1 \mathrm{~m}$ tall interspersed with "motts" of taller hybrid plants (Muller 1951). Forage production can be reduced as much as $90 \%$ under dense stands (McIlvain 1954). To control oak and increase herbaceous yield, oak-infested rangeland is currently treated with the pelleted herbicide tebuthiuron ( $N-[5-(1,1$-dimethylethyl)-1,3,4,thiadiazol-2-yl]- $N, N$-dimethylurea). Pettit (1979) reported that $1.0 \mathrm{~kg}$ a.i. / ha of tebuthiuron resulted in total oak kill in studies at the same research location. Grass yields following application of tebuthiuron increased from 3- to 9-fold 2 growing seasons after herbicide application (Pettit 1979).

Herbicides can alter internal ecosystem functions as well as external appearance. Little is known of the effects of herbicides on ecosystem functions such as biomass dynamics and nutrient cycling.

Since herbicidal-induced death of oak should alter biomass dynamics in the sand shinnery oak-grassland ecosystem, this study was designed to evaluate an untreated oak community as contrasted to similar areas treated with tebuthiuron 3 years (1978) and

Authors are research assistant, associate professor, research scientist, and associate professor, Department of Range and Wildlife Management, Texas Tech University, Lubbock 79409. This is a contribution of the College of Agricultural Sciences, Texas Tech University, Publication Number T-9-383.

This research was partially funded by Elanco Products Division of Eli Lilly and Company.

Manuscript accepted 26 December 1986.
6 years (1975) prior to sampling. One specific objective was to evaluate weights of above- and below-ground biomass on each of the 3 sites.

\section{Methods and Procedure}

Research was conducted in south-central Cochran $\left(33^{\circ} 23^{\prime} \mathrm{N}\right.$ and $\left.102^{\circ} 46^{\prime} \mathrm{W}\right)$ and north-central Yoakum $\left(33^{\circ} 21^{\prime} \mathrm{N}\right.$ and $\left.102^{\circ} 38^{\prime} \mathrm{W}\right)$ counties, approximately $25 \mathrm{~km}$ north and $5 \mathrm{~km}$ east of Plains, Texas. Study areas are in the southern Great Plains in a sand dune system originating in eastern New Mexico. Sites are characterized by rolling sand hills interspersed with semistabilized dunes and blow-out areas.

Climate of the area is warm-temperate and continental with an average annual precipitation of $40 \mathrm{~cm}$ (Soil Survey Staff 1964). Rainfall for 1980 and 1981 was 33.4 and $55.6 \mathrm{~cm}$, respectively, Precipitation patterns are characterized by widely scattered intense thunderstorms in spring and late summer. Temperatures range from $44^{\circ}$ to $-25^{\circ} \mathrm{C}$ with a frost-free period of approximately 200 days.

The primary soil on the study areas is a Brownfield fine sand (fine, mixed, thermic Arenic Aridic Paleustalf) (Soil Survey Staff 1964). It is characterized by an A horizon of approximately $95 \%$ sand, ranging from 40 to $70 \mathrm{~cm}$ deep, overlying a sandy clay loam argillic B horizon. The water holding capacity of this soil is low. Infiltration rates are rapid (up to $70 \mathrm{~cm} / \mathrm{hr}$ ), and percolation is rapid until the wetting front reaches the $B$ horizon.

Species composition of the study area was described by Pettit (1979) and by Jones (1982). The plant community consists of tall-to mid-grass species and increaser short-grass species under a dense canopy of sand shinnery oak. Following treatment of this oak community with tebuthiuron, physiognomy was changed from oak shrubland to mixed-grass prairie. Sand shinnery oak and sand sagebrush were absent on the treated sites. The major grass species were the same. However, the number of forb species was higher on the 2 treated areas than on the control.

Three, $15 \times 30-\mathrm{m}$ study areas were established (1) in an untreated sand shinnery oak grassland, (2) in a similar community treated with tebuthiuron at $0.6 \mathrm{~kg}$ a.i./ ha 3 years (1978) prior to sampling. and (3) in a similar community treated 6 years (1975) prior to sampling. All 3 sites had similar vegetative composition, occur on Brownfield soils and have been grazed lightly from June to September. All 9 study areas were fenced prior to sampling to exclude grazing during the study. A 30-point grid was established within each study area, and 4 sample points were randomly selected per area for each sampling date (April, growth initiation; July, peak standing crop; and December, dormancy). Samples were collected for above- and below-ground plant compartments.

Above-ground biomass was harvested at ground level in a $1-\mathrm{m}^{2}$ circular quadrat at each sample point and separated by compart- 
ment. Above-ground compartments sampled were: live oak stems, dead oak stems, live oak leaves, live herbaceous shoots (grass and forb shoots combined), dead herbaceous shoots, and litter.

Soil in a $0.25-\mathrm{m}^{2}$ circular plot at each sample point was excavated to depths of (1) 0 to $15 \mathrm{~cm}$, (2) 15 to $30 \mathrm{~cm}$, (3) $30 \mathrm{~cm}$ to the top of the $B_{2} t$ horizon, and (4) $15 \mathrm{~cm}$ into the $B_{2} t$ horizon. Depth effects were evaluated using weights adjusted to $15-\mathrm{cm}$ increments for the variable increment ( $30 \mathrm{~cm}$ to the top of the argillic horizon) resulting in a $60-\mathrm{cm}$ soil profile sample for all 3 treatments. The soil in each depth increment was placed in separate burlap bags and transported to the laboratory for root separation. Soil from each depth layer was sieved to pass a double layer of $1.6-\mathrm{mm}$ mesh screen to recover the fine root fragments. Below-ground biomass was separated into large oak roots $(>2 \mathrm{~mm})$, small oak roots $(<2$ $\mathrm{mm}$ ), and herbaceous roots (grass and forb roots combined). Vegetative samples were dried to a constant weight in a forced air oven $\left(60^{\circ} \mathrm{C}\right)$ and then weighed to the nearest $0.01 \mathrm{~g}$.

Total seasonal biomass was calculated by adding biomass across sampling dates for each treatment. Biomass for each compartment was analyzed in a completely randomized design with 3 replications and 4 samples per replication. Treatments were main plots and sampling dates were subplots in a repeated measured analysis.

Table 1. Seasonal biomass ( $\mathrm{kg} / \mathrm{ha}$ ) for major compartments on control, 3-year old and 6-year old tebuthiuron treated sand shinnery rangeland in west Texas.

\begin{tabular}{|c|c|c|c|c|c|c|c|c|c|c|c|c|}
\hline \multirow[b]{3}{*}{ Compartment } & \multicolumn{12}{|c|}{ Treatment } \\
\hline & \multicolumn{3}{|c|}{ Control } & \multicolumn{3}{|c|}{ 3-Year } & \multicolumn{3}{|c|}{ 6-Year } & \multicolumn{3}{|c|}{ Average } \\
\hline & April & July & Dec. & April & July & Dec. & April & July & Dec. & Control & 3-Year & 6-Year \\
\hline $\begin{array}{l}\text { Total oak } \\
\text { Total herbaceous } \\
\text { Total litter } \\
\text { Total biomass }\end{array}$ & $\begin{array}{c}23909 \\
1355 b^{2} \\
7671 \\
32935\end{array}$ & $\begin{array}{c}21913 \\
1601 \mathrm{c} \\
6288 \\
29803\end{array}$ & $\begin{array}{c}21713 \\
1887 \mathrm{c} \\
8987 \\
32588\end{array}$ & $\begin{array}{c}19671 \\
3746 \mathrm{a} \\
5076 \\
28494\end{array}$ & $\begin{array}{c}20236 \\
6986 \mathrm{a} \\
6676 \\
33898\end{array}$ & $\begin{array}{c}16325 \\
7001 \mathrm{a} \\
7364 \\
30689\end{array}$ & $\begin{array}{c}14894 \\
3838 \mathrm{a} \\
5221 \\
23953\end{array}$ & $\begin{array}{c}12918 \\
4815 b \\
3679 \\
21413\end{array}$ & $\begin{array}{c}11937 \\
3969 \mathrm{~b} \\
6715 \\
22621\end{array}$ & $\begin{array}{c}22512 \mathrm{~A}^{1} \\
1614 \\
7649 \mathrm{~A} \\
31775 \mathrm{~A}\end{array}$ & $\begin{array}{c}18744 \mathrm{~B} \\
5911 \\
6372 \mathrm{AB} \\
31027 \mathrm{~A}\end{array}$ & $\begin{array}{c}13250 \mathrm{C} \\
4207 \\
5205 \mathrm{~B} \\
22663 \mathrm{~B}\end{array}$ \\
\hline
\end{tabular}

${ }^{1}$ Treatment averages for each compartment followed by the same upper case letter are not significantly different $(P>0.05)$.

2Treatment means for each compartment within a sampling date followed by the same lower case letter are not significantly different $(P>0.05$ ).

Table 2. Seasonal biomass (kg/ha) dynamics for above-ground compartments on control, 3-year old and 6-year old tebuthiuron treated sand shinnery rangeland in west Texas.

\begin{tabular}{|c|c|c|c|c|c|c|c|c|c|c|c|c|}
\hline \multirow[b]{3}{*}{ Compartment } & \multicolumn{12}{|c|}{ Treatment } \\
\hline & \multicolumn{3}{|c|}{ Control } & \multicolumn{3}{|c|}{ 3-Year } & \multicolumn{3}{|c|}{ 6-Year } & \multicolumn{3}{|c|}{ Average } \\
\hline & April & July & Dec. & April & July & Dec. & April & July & Dec. & Control & 3-Year & 6-Year \\
\hline Live oak stems ${ }^{1}$ & 724 & 681 & 691 & 0 & 0 & 0 & 0 & 0 & 0 & 699 & 0 & 0 \\
\hline Dead oak stems' & 530 & 253 & 0 & 0 & 0 & 0 & 0 & 0 & 0 & 261 & 0 & o \\
\hline $\begin{array}{l}\text { Live oak leaves }{ }^{1} \\
\text { Total above-ground } 1\end{array}$ & 0 & 1140 & 0 & 0 & 0 & 0 & 0 & 0 & 0 & 380 & 0 & 0 \\
\hline $\begin{array}{l}\text { oak } \\
\text { Live herbaceous }\end{array}$ & 1254 & 2072 & 692 & 0 & 0 & 0 & 0 & 0 & 0 & 1139 & 0 & 0 \\
\hline $\begin{array}{l}\text { shoots } \\
\text { Dead herbaceous }\end{array}$ & $24 \mathrm{a}^{2}$ & $183 c$ & $75 a$ & $18 \mathbf{a}$ & $1536 \mathrm{~b}$ & $35 \mathrm{a}$ & $39 a$ & $1826 a$ & $121 \mathrm{a}$ & 94 & 530 & 662 \\
\hline $\begin{array}{l}\text { shoots } \\
\text { Total above-ground }\end{array}$ & $239 \mathrm{~b}$ & $24 b$ & $202 c$ & $291 \mathrm{~b}$ & $193 a$ & $2252 a$ & $706 a$ & $459 \mathrm{a}$ & $1431 b$ & 155 & 912 & 865 \\
\hline $\begin{array}{l}\text { herbaceous } \\
\text { Above-ground liter } \\
\text { Total above-ground }\end{array}$ & $\begin{array}{r}263 b \\
4081 a\end{array}$ & $\begin{array}{r}207 c \\
2047 a\end{array}$ & $\begin{array}{r}277 \mathrm{c} \\
3252 \mathrm{a}\end{array}$ & $\begin{array}{l}309 \mathrm{ab} \\
2666 \mathrm{~b}\end{array}$ & $\begin{array}{l}1730 \mathrm{~b} \\
2509 \mathrm{a}\end{array}$ & $\begin{array}{l}2287 a \\
2384 a b\end{array}$ & $\begin{array}{r}745 a \\
1732 c\end{array}$ & $\begin{array}{l}2285 a \\
1748 a\end{array}$ & $\begin{array}{l}1552 b \\
2109 b\end{array}$ & $\begin{array}{r}249 \\
3126\end{array}$ & $\begin{array}{l}1442 \\
2519\end{array}$ & $\begin{array}{l}1527 \\
1863\end{array}$ \\
\hline biomass & $5598 \mathrm{a}$ & $4327 a$ & $4220 \mathrm{a}$ & $2975 b$ & $4238 a$ & $4671 a$ & $2477 b$ & $4033 a$ & $3661 a$ & 4715 & 3961 & 3390 \\
\hline
\end{tabular}

1Biomass in these compartments was not present in 3-year old and 6-year old treatments.

2Treatment means for each compartment at each sampling date followed by the same letter are not significantly different $(P>0.05)$.

Table 3. Seasonal biomass (kg/ha) for below-ground compartments on control, 3-year old and 6-year old tebuthiuron treated sand shinnery rangeland in west Texas.

\begin{tabular}{|c|c|c|c|c|c|c|c|c|c|c|c|c|}
\hline \multirow[b]{3}{*}{ Compartment } & \multicolumn{12}{|c|}{ Treatment } \\
\hline & \multicolumn{3}{|c|}{ Control } & \multicolumn{3}{|c|}{ 3-Year } & \multicolumn{3}{|c|}{ 6-Year } & \multicolumn{3}{|c|}{ Average } \\
\hline & April & July & Dec. & April & July & Dec. & April & July & Dec. & Control & 3-Year & 6-Year \\
\hline $\begin{array}{l}\text { Large oak roots } \\
(>2 \mathrm{~mm})\end{array}$ & 16161 & 14003 & 14609 & 15627 & 14610 & 10827 & 10829 & 8329 & 7213 & $14924 A^{\prime}$ & $13688 A$ & 8790B \\
\hline $\begin{array}{l}\text { Small oak roots } \\
(<2 \mathrm{~mm})\end{array}$ & 6494 & 5839 & 6412 & 4044 & 5626 & 5497 & 4066 & 4589 & 4725 & $6248 \mathrm{~A}$ & $5056 \mathrm{~B}$ & $4460 B$ \\
\hline Total oak roots & 22655 & 19841 & 21022 & 19671 & 20236 & 16325 & 14894 & 12918 & 11937 & $21173 A$ & 18744B & $13250 \mathrm{C}$ \\
\hline Herbaceous roots & 1092 & 1394 & 1610 & 3437 & 5256 & 4714 & 3093 & 2530 & 2418 & $1365 \mathrm{C}$ & $4469 A$ & $2680 B$ \\
\hline Belowground litter & 3591 & 4241 & 5735 & 2410 & 4167 & 4980 & 3489 & 1931 & 4606 & $4522 A$ & $3852 A$ & $3342 A$ \\
\hline Total belowground & 27338 & 25476 & 28367 & 25519 & 29659 & 26018 & 21476 & 17380 & 18961 & $27060 \mathrm{~A}$ & $27065 A$ & $19272 B$ \\
\hline
\end{tabular}

'Treatment averages for each compartment followed by the same letter are not significantly different $(P>0.05)$. 


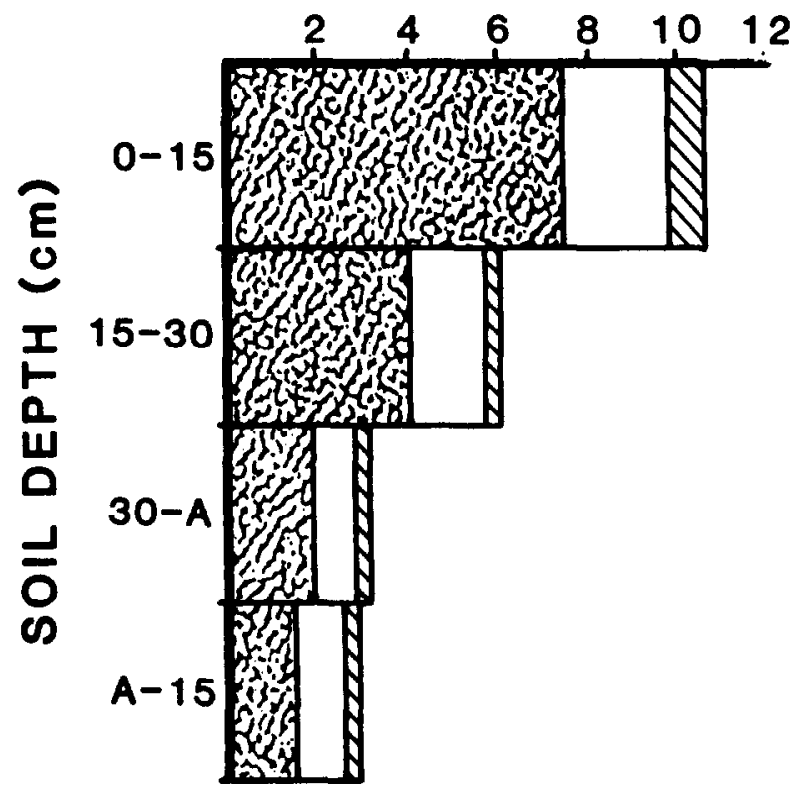

CONTROL

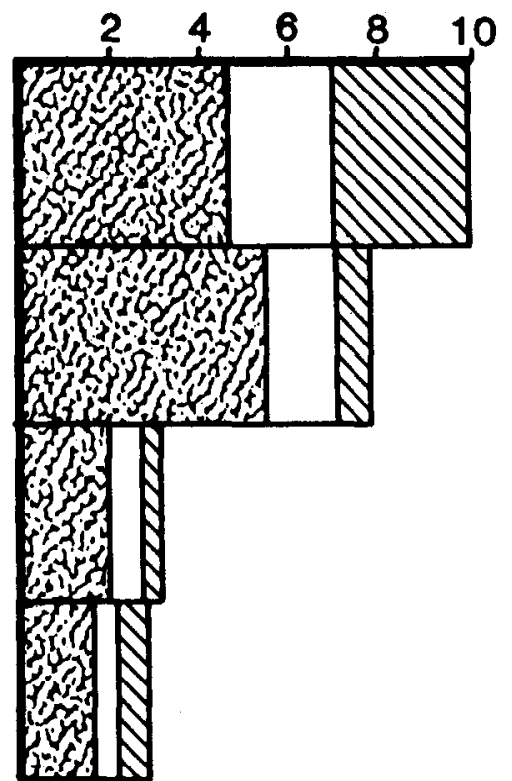

3-YEAR

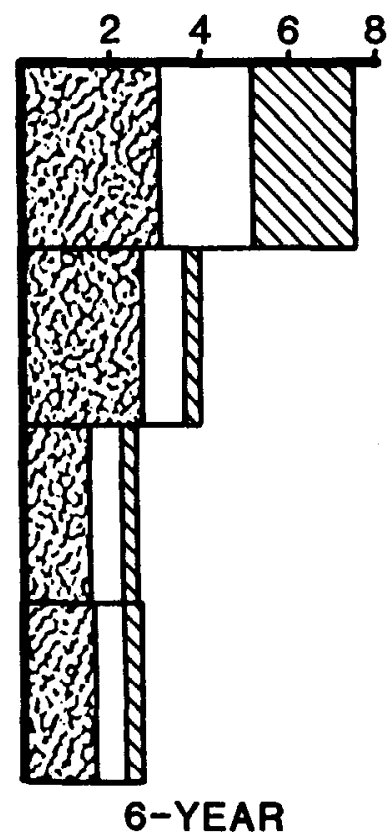

TREATMENT

\section{OAK $(\mathrm{g}) \square$ OAK $(\mathrm{gm}) \quad \square$ HERBACEOUS}

Fig. 1. Root biomass $(\mathrm{kg} / \mathrm{ha})$ by soil depth for herbicide treated sand shinnery oak rangeland in west Texas as affected by treatment.

Primary interest focused on treatment comparison. When dates and treatments interacted, treatments were compared within each date (e.g., Steel and Torrie 1980:386) with Duncan's new multiple range Test. Below-ground biomass was analyzed as a completely randomized design in a split-plot arrangement. Each sampling date was analyzed separately; treatments were main plots and depths were subplots in the split-plot arrangement. Primary interest focused on treatment comparison. When depths and treatments interacted, treatments were compared within each depth with Duncan's new multiple range test.

\section{Results and Discussion}

Total biomass on 3-year and 6-year post tebuthiuron treatment plots was $3 \%$ and $29 \%$, respectively, less than the untreated plot (Table 1). Yearly biomass production increased following application of tebuthiuron, whereas total biomass was only slightly changed. The increase occurred because grasses and forbs, dominants on the treated areas, regenerated the majority of their aboveground biomass and a percentage of their below-ground biomass each year, while the majority of the oak biomass is woody and long-lived. The total biomass remained relatively unchanged because of the slow decomposition of oak roots on the 2 treated

Table 4. Below-ground biomass (kg/ha) for major compartments at four soil depths on control, 3-year-old and 6-year old tebuthiuron treated sand shinnery oak rangeland in west Texas.

\begin{tabular}{|c|c|c|c|c|c|c|c|c|c|c|}
\hline \multirow[b]{2}{*}{ Compartment } & \multirow[b]{2}{*}{ Depth } & \multicolumn{3}{|c|}{ April } & \multicolumn{3}{|c|}{ July } & \multicolumn{3}{|c|}{ December } \\
\hline & & Control & 3-Year & 6-Year & Control & 3-Year & 6-Year & Control & 3-Year & 6-Year \\
\hline Large oak roots & $\begin{array}{c}1 \\
2 \\
3 \\
4 \\
\text { Avg }\end{array}$ & $\begin{array}{l}7509 \mathrm{a}^{1} \\
5118 \mathrm{~b} \\
2028 \mathrm{a} \\
1506 \mathrm{a} \\
4040\end{array}$ & $\begin{array}{l}4621 b \\
7193 a \\
2160 a \\
1653 a \\
3907\end{array}$ & $\begin{array}{l}4140 b \\
3218 b \\
1273 a \\
2198 a \\
2707\end{array}$ & $\begin{array}{l}7087 \mathrm{a} \\
4007 \mathrm{ab} \\
1561 \mathrm{a} \\
1348 \mathrm{a} \\
3501\end{array}$ & $\begin{array}{l}6340 \mathrm{a} \\
5003 \mathrm{ab} \\
1570 \mathrm{a} \\
1698 \mathrm{a} \\
3653\end{array}$ & $\begin{array}{l}2795 b \\
2553 b \\
1293 a \\
1688 a \\
2082\end{array}$ & $\begin{array}{l}7702 a \\
3273 a \\
2139 a \\
1495 a \\
3652\end{array}$ & $\begin{array}{l}3063 \mathrm{~b} \\
4386 \mathrm{a} \\
1797 \mathrm{a} \\
1582 \mathrm{a} \\
2707\end{array}$ & $\begin{array}{l}2440 \mathrm{~b} \\
2464 \mathrm{a} \\
1170 \mathrm{a} \\
1138 \mathrm{a} \\
1803\end{array}$ \\
\hline Small oak roots & $\begin{array}{c}1 \\
2 \\
3 \\
4 \\
\text { Avg }\end{array}$ & $\begin{array}{l}2112 a \\
1804 a \\
1220 a \\
1358 a \\
1624\end{array}$ & $\begin{array}{c}1539 b \\
1293 b \\
613 b \\
600 b \\
1011\end{array}$ & $\begin{array}{c}2157 \mathrm{a} \\
1042 \mathrm{~b} \\
368 \mathrm{~b} \\
499 \mathrm{~b} \\
1017\end{array}$ & $\begin{array}{c}2462 \\
1374 \\
918 \\
1085 \\
1460 A^{2}\end{array}$ & $\begin{array}{c}2814 \\
1579 \\
605 \\
628 \\
1407 A\end{array}$ & $\begin{array}{r}2082 \\
2159 \\
987 \\
586 \\
857 \\
1147 \mathrm{~A}\end{array}$ & $\begin{array}{c}5032 \\
2314 \\
2112 \\
1043 \\
943 \\
1603 A\end{array}$ & $\begin{array}{c}2707 \\
2280 \\
1740 \\
992 \\
485 \\
1374 A\end{array}$ & $\begin{array}{c}1803 \\
2207 \\
1091 \\
818 \\
610 \\
1182 A\end{array}$ \\
\hline Herbaceous roots & $\begin{array}{c}1 \\
2 \\
3 \\
4 \\
\text { Avg }\end{array}$ & $\begin{array}{l}589 \mathrm{~b} \\
185 \mathrm{a} \\
147 \mathrm{a} \\
170 \mathrm{a} \\
273\end{array}$ & $\begin{array}{r}2422 a \\
385 a \\
195 a \\
436 a \\
860\end{array}$ & $\begin{array}{r}2817 a \\
153 a \\
44 a \\
79 a \\
773\end{array}$ & $\begin{array}{l}870 \mathrm{c} \\
162 \mathrm{~b} \\
128 \mathrm{a} \\
233 \mathrm{a} \\
348\end{array}$ & $\begin{array}{r}3697 a \\
873 a \\
242 a \\
444 a \\
1314\end{array}$ & $\begin{array}{c}2003 b \\
259 b \\
121 a \\
148 a \\
633\end{array}$ & $\begin{array}{l}824 c \\
158 a \\
301 a \\
327 a \\
403\end{array}$ & $\begin{array}{r}3179 \mathrm{a} \\
746 \mathrm{a} \\
363 \mathrm{a} \\
426 \mathrm{a} \\
1179\end{array}$ & $\begin{array}{c}1924 b \\
217 a \\
115 a \\
161 a \\
604\end{array}$ \\
\hline
\end{tabular}

1'Treatment means within a depth for each compartment and each sampling date followed by the same lower case letter are not significantly different ( $P>0.05$ ).

${ }^{2}$ Treatment means for each compartment and each sampling date followed by the same upper case letter are not significantly different $(P>0.05)$. 
plots. Below-ground oak biomass comprised $67 \%$ of the total biomass on the control and was $60 \%$ on the 3 -year-old and $58 \%$ on the 6-year-old treated plots.

\section{Above-ground Biomass}

Total above-ground biomass decreased $16 \%$ on the plots sampled 3 years after treatment but decreased $28 \%$ on the plots sampled 6 years after treatment compared to untreated rangeland (Table 2). Above-ground biomass decreased following herbicide treatment because of the loss of oak and the decline in litter. Standing oak comprised $28 \%$ of the above-ground biomass on the control but was absent on the 2 treated areas.

Herbaceous biomass was 6-fold greater on the 3-year-old and 6-year-old treatments compared to the untreated rangeland. The 6-fold increase in above-ground herbaceous matter following herbicide treatment was similar to the 4- to 9-fold increases reported by Pettit (1979). Herbaceous yield (live and standing dead) on the untreated plots $(249 \mathrm{~kg} / \mathrm{ha}$ ) was below the range of weights ( 820 to $5,980 \mathrm{~kg} / \mathrm{ha}$ ) listed for 10 North American grassland communities by Sims and Coupland (1979). However, the 3-year-old and 6-yearold treatments $(1,442$ and $1,527 \mathrm{~kg} / \mathrm{ha}$, respectively) were in that range. The decrease in standing dead biomass from April to July and the increase from July to December reflected dynamics of recent-dead material as discussed by Sims and Coupland (1979). The recent-dead material increased as the growing season progressed, usually beginning midway through the season and peaking at the end of the season. The decrease from April to July was due to dead material being transferred to the litter compartment.

Above-ground litter biomass decreased $20 \%$ from the untreated plots to the 3-year-old treatment and $41 \%$ from the control to the 6-year-old treatment. Above-ground litter dynamics were different on all 3 treatments. Litter on the untreated plot consisted primarily of oak stem and leaf material with a small portion of herbaceous leaves and stems. The 3-year-old treatment still had decomposing oak stems and a large amount of fine herbaceous material. On the 6-year-old treatment there were no leaves and few oak stems but large amounts of fine herbaceous material. The varied sources for litter, coupled with the variable rates of litter disappearance, lead to erratic litter dynamics; however, most grasslands display a peak in litter biomass early in the season (Sim and Coupland 1979).

\section{Below-ground Biomass}

Total below-ground biomass was essentially the same on the 3-year-old treatment and on the control but decreased $28 \%$ on the 6-year-old treatment when compared to the control (Table 3). Below-ground biomass ranged from 85 to $88 \%$ of the total biomass for the 3 treatments and corresponded to the 68 to $98 \%$ reported for 10 North American grassland communities (Sims and Singh 1971).

Mean root biomass on the IBP grassland study areas ranged from $1,870 \mathrm{~kg} / \mathrm{ha}$ in a desert grassland to $19,600 \mathrm{~kg} / \mathrm{ha}$ in mixedgrass prairie (Sims and Coupland 1979). Root biomass on the 6-year-old treatment $(15,930 \mathrm{~kg} / \mathrm{ha})$ fit into that range, while weights for the untreated plot $(22,538 \mathrm{~kg} / \mathrm{ha})$ and 3 -year-old treatment $(23,213 \mathrm{~kg} / \mathrm{ha})$ were slightly higher. The large amount of oak roots was responsible for the higher weights.

Root biomass decreased with soil depth and the pattern of vertical distribution was similar on all treatments (Table 4). The decrease in total roots with depth has been previously documented (Weaver and Zink 1946, Dahlman and Kucera 1965, Christie 1981).

Oak roots made up 94,81 , and $83 \%$ of the total root biomass on the untreated 3-year-old and 6-year-old plots, respectively. Large oak root biomass was $8 \%$ less on the 3 -year-old treatment and $41 \%$ less on the 6-year-old treatment compared to the untreated rangeland (Table 3). Small oak root biomass was reduced $19 \%$ on the 3-year-old plot and $29 \%$ on the 6-year-old plot compared to the untreated plot. The low rate of oak root decomposition on the treated sites may reflect high lignin content and low soil and root nitrogen. High initial levels of lignin may slow decomposition (Melillo et al. 1982) and low amounts of nitrogen limit decomposi- tion (Weaver 1947). The $\mathrm{C} / \mathrm{N}$ ratio for the large oak roots ranged from 86 to 92 . Alexander (1961) indicated that $C / N$ ratios greater than 20 favor immobilization of nitrogen and slow decomposition rates.

Both large and small oak roots decreased on the untreated area from April to July. A decrease in small oak roots $(<\mathrm{mm}$ dia.) through the growing season was reported for tree roots by Hermann (1977). A decrease has not been reported for large roots, however, Harris et al. (1977) stated that large roots $(>5 \mathrm{~mm}$ dia.) were more stable and showed no significant or annual change. The trend towards a decrease in large oak root biomass from April to July on the untreated site may reflect decomposition of the component dead oak root material. Herbaceous roots increased 3-fold 3 years and 2 -fold 6 years following treatment compared to the untreated plots (Table 3 ). These increases corresponded to increases in above-ground herbaceous biomass. Changes in herbaceous roots through the growing season on the untreated and 3-year-old treated plots were consistent with data reported for grassland ecosystems (Wiegert and Evans 1964, Dahlman and Kucera 1965, Hulett and Tomanek 1971). The trend toward decreased amounts of herbaceous roots later in the season on the 6-year-old treatment may reflect the high density of winter annual forbs on the site that died before July then decomposed rapidly.

Herbaceous root distribution with depth differed by treatment as a result of changed rooting behavior following herbicidal treatment (Table 4). On the 3-year-old and 6-year-old treatments 84 and $92 \%$ of the herbaceous roots were in the surface $30 \mathrm{~cm}$, which was similar to, although slightly higher than, the $80 \%$ average reported by Sims and Singh (1971) for 10 IBP grasslands and the 81 to $87 \%$ range in the surface $25 \mathrm{~cm}$ reported by Dahlman and Kucera (1975). The untreated area, with only $68 \%$ of the herbaceous roots in the surface $30 \mathrm{~cm}$, was below the average values for grasslands. The untreated area had a greater percentage of herbaceous roots in the argillic layer than the 2 treated sites. All 3 sites showed an increase in herbaceous roots in the argillic layer compared to the soil layer above. This increase, although not the normal situation in most grasslands, was described by Cannon (1913). In soils with a subsoil of adjacent layers of sand and clay, the roots often occur abundantly near the bottom of the sandy layers and in the clay layer when the latter, acting as a rather impervious layer, has retained much more soil moisture. Test (1972) described this phenomenon in the Brownfield soil.

\section{Root/Shoot Ratios}

Root/shoot ratios were important for understanding the distribution of energy between below-ground and above-ground compartments. The root/shoot ratio for sand shinnery oak (recorded for July only) was 11 on the untreated control area, which was similar to the ratio of 9 reported by Pettit and Deering (1970). No root/shoot ratios for oak on the 2 treated areas were calculated due to oak death and the absence of oak shoot biomass.

Root/shoot ratios of herbaceous matter decreased from 6 on the untreated plot to 3 on the 3-year-old treatment to 1.8 on the 6-year-old treatment. Ratios for IBP grasslands ranged from 2 to 13 (Sims et al. 1978). The ratios on the untreated and 3-year-old treatments were within that range. The ratio on the 6-year-old treatment was slightly lower than the average range of values for grasslands. The low root/shoot ratio on the 6-year-old treatment was probably due to the abundance of annual forbs and short grass species with small root systems. The high ratio on the untreated site reflected low herbaceous production in the untreated oak community because of competition with the oak.

\section{Summary and Conclusions}

Following tebuthiuron application to sand shinnery oak communities, the most obvious change has been in oak biomass. Even with the fairly rapid disappearance of above-ground oak biomass, oak roots have decomposed slowly. There was a $12 \%$ decrease of oak root biomass from the control to the 3-year-old treatment and 
a 37\% decrease from the control to the 6-year-old treatment. The slow breakdown of oak root material may be a result of the low natural fertility of these sandy soils and the high $\mathrm{C} / \mathrm{N}$ ratios of the oak root and rhizome material.

Another obvious change has been an increase in herbaceous yield on the treated sites. Reduction in oak competition resulted in increased availability of moisture and nutrients for grass growth. Increased herbaceous yield has continued for 6 years following treatment. The increase in herbaceous roots and the change to a more shallow root system has increased the ability of the herbaceous plants to obtain water and nutrients.

Total biomass will probably continue to decrease on the treated areas as the oak decomposes. This should not be misconstrued as a decrease in productivity on the site. Above-ground live biomass on the control area was approximately double that on the 2 treated areas. Ninety-two percent of the above-ground live biomass on untreated areas was long-lived woody oak material. Only $8 \%$ of the live material was herbaceous on the untreated area, whereas on the treated sites $100 \%$ of the above-ground biomass was herbaceous.

\section{Literature Cited}

Alexander, M. 1961. Introduction to soil microbiology. John Wiley and Sons, Inc., New York.

Allred, B.W. 1956. Mixed Prairie in Texas. p. 267-283, In: Grasslands of the Great Plains. Johnson Pub. Co., Lincoln.

Cannon, W.A. 1913. Notes on root variation in some desert plants. Plant World 16:323.

Chriatie, E.K. 1981. Biomass and nutrient dynamics in a $C_{4}$ semi-arid Australian grassland community. J. Appl. Ecol. 18:907-918.

Dahlman, R.C., and C.L. Kucera. 1965. Root productivity and turnover in native prairie. Ecology 46:84-89.

Harris, W.F., R.S. Kinerson, Jr., and N.T. Edwards. 1977. Comparison of below-ground biomass of natural deciduous forests and loblolly pine plantations. p. 29-38. In. J.K. Marshall (ed.). The Below-ground Ecosystem: A Synthesis of Plant-associated Processes. Range Science Department Science Series No. 26, Colorado State University, Fort Collins.

Hulett, G.K., and G.W. Tomanek. 1971. Herbage dynamics on a mixed prairie grassland, 1968-1970. US/IBP Grassland Biome Tech. Rep. No. 156. Colorado State Univ., Fort Collins.
Jones, V.E. 1982. Effects on tebuthiuron on a sand shinnery oak (Quercus havardii) community. Ph.D. Dissertation, Texas Tech Univ., Lubbock.

Mellvain, E.H. 1954. Interim report on shinnery oak control studies in the southern Great Plains. Proc. 11 th meeting North Cen. Weed Control Conf. 11:95-96.

Melillo, J.M., J.D. Aber, and J.F. Muratore. 1982. Nitrogen and lignin control of hardwood leaf litter decomposition dynamics. Ecology 63:621-626.

Muller, C.H. 1951. The significance of vegetative reproduction in Quercus. Madrono 11:129-137.

Pettit, R.D. 1979. Effects of picloram and tebuthiuron pellets on sand shinnery oak communities. J. Range Manage. 32:196-200.

Pettit, R.D., and D.W. Deering. 1970. Sand shinnery oak control. In: Noxious Brush and Weed Control Highlights-1970. 1:8. Texas Tech Univ., Lubbock.

Sims, P.L., and R.T. Coupland. 1979. Producers, Part Il. Natural temperate grasslands. p. 49-85. In: R.T. Coupland (ed.). Grassland Ecosystems of the World: Analysis of Grasslands and Their Uses. IBP 18. Cambridge Univ. Press. New York.

Sims, P.L., and J.S. Singh. 1971. Herbage dynamics and net primary production in certain ungrazed and grazed grasslands in North America. p. 59-113. In: N.R. French (ed.). Preliminary Analysis of Structure and Function in Grasslands. Range Sciences Department Series 10. Colorado State Univ., Fort Collins.

Sims, P.L., J.S. Singh, and W.K. Lauenroth. 1978. The structure and function of ten western North American grasslands. I. Abiotic and vegetational characteristics. J. Ecol. 66:251-85.

Soll Survey Staff. 1964. Soil survey of Yoakum County, Texas. Soil Conservation Service. USDA Series 1960, No. 15.

Steel, R.G.D., and J.H. Torrie. 1980. Principles and procedures of statistics. McGraw-Hill Book Co., Inc., New York.

Test, P.S. 1972. Soil moisture depletion and temperature affected by sand shinnery oak (Quercus havardii) Rydb.) control. M.S. Thesis, Texas Tech Univ., Lubbock, Texas.

Weaver, J.E. 1947. Rate of decomposition of roots and rhizomes of certain range grasses in undisturbed prairie soil. Ecology 28:221-240.

Weaver, J.E., and E. Zink. 1946. Annual increase of underground materials in 3 range grasses. Ecology 27:115-127.

Wiegert, R.G., and F.C. Evans. 1964. Primary production and disappearance of dead vegetation on an old field in southeastern Michigan. Eco$\operatorname{logh}$ 45:49-63. 